\title{
Roman Demydenko
}

SESE "The Academy of Financial Management",

Kyiv, Ukraine, moamasterknu@gmail.com

ORCID ID https://orcid.org/0000-0001-6508-9577

\section{NORMING OF SCIENTIFIC AND RESEARCHING LABOUR: CONCEPTUAL SOURCES}

\begin{abstract}
The study is dedicated to the problems of standardization and quality management of scientific labour that is characterized as a highly creative and undefined. It is pointed out that the unified international approach to collecting and processing scientific information would influence many spheres of science. Particularly, the opportunity to enhance the level of efficiency of quantitative and qualitative results of research performance can be fulfilled by implementing theoretical and methodological components of the norming of scientific and research labour (NSRL) conception. Supporting previous contribution to the issues, it has to be agreed with the hypothesis that a partial evaluation of human resource in research and development environment could take place despite the complexity of external appearances of creativity of the scientist. Generally, NSRL conception describes the prospective ability to stimulate the evolution of intellectual capital in the sphere of RED. The concept of NSRL consists of the definition, triad of principles of implementation and performance, interconnection of NSRL functions and RED management components, NSRL cyclic process of application, stakeholders' environment with NSRL roles allocation, terminal and level effects clarification of NSRL utilization and division of NSRL priorities. NSRL can be identified as a few objective concepts such as policy, practice, culture. Adaptation of concept is being highly applicable because of the analogy in the production industrial sphere, where exact instruments have made a notable impact on human resource stimulation. Some suggestions on implementation and further evolution of the topic have been declarated. One of the strongest directions is the possibility to shape management accounting techniques for the analysis in the scientific sphere. Appropriate cost optimization would cause incremental changes on the way of obtaining various investments because of the increase of reporting transparency.

Ke ywords: norming of scientific and research labour (NSRL), research and development $(R \& D)$, standardization of research effectiveness and efficiency assessment, scientific and research labour standardization, intellectual capital, quality management and accounting in the scientific sector, innovational development project management.
\end{abstract}

JEL classification: H83, I22, I23, I28, L15, M49, M51, M52, M54,

O22, O32, O34, 038

\section{Демиденко Р. К.}

аспірант НДФІ ДННУ “Академія фінансового управління",

Київ, Україна, moamasterknu@gmail.com

ORCID ID https://orcid.org/0000-0001-6508-9577

\section{НОРМУВАННЯ НАУКОВО-ДОСЛІДНОЇ ПРАЦІ: КОНЦЕПТУАЛЬНІ ВИТОКИ}

Анотація. Розглянуто проблеми стандартизацї̈ у науковій діяльності та особливості оцінювання якості результатів наукових досліджень в умовах міжнародної унібікації. Мета дослідження - формування теоретичних та методологічних підходів до нормування науково-дослідної праці. На основі порівняльного аналізу літературних джерел, чинної нормативної бази та

(ㄷ Аемиденко Р. К., 2020

Наукові праці НДФІ • 2020 • № 1 (90) 
практики визначено сутність і окремі кількісні критерї̈ нормування наукової праці. Ідентифіковано функиії нормування прачі вченого й систематизовано бундаментальні принципи нормування творчої праці у науковій сбері. Структуровано середовище нормування інтелектуальної прачі науковця із встановленням внутрішньої та зовнішньої складових $і$ рівня виливу. Виокремлено спільні та відмінні риси міжк категоріями нормування наукової прачі та оцінювання якості й ефективності наукової діяльності. Здійснено класибікацію ебектів від упровадження нормування науково-дослідної праці. Охарактеризовано множину взаємозв'язків нормування наукової прачі та фінансування наукової, науково-технічної діяльності. Обтрунтовано роль нормування науково-дослідної праці у досягненні конкурентних переваг у науковій сбері. Окреслено перспективи розвитку підходів до нормування праці науковия та можливості вдосконалення ії методології.

К $\Lambda$ юч о в і с $\Lambda$ ов а: нормування науково-досліАної праці (ННАП), АосліАження і розробки (АіP), стандартизація оцінювання резумьтативності та ефективності наукових досліджень, стимулювання науково-дослідної праці, інтелектуальний капітал, управління якістю та облік у науковому сектоpi, управміння проектами інноваційного розвитку.

Табц. 2 Рис. 4. Міт. 33.

Демиденко Р. К.

аспирант НИФИ ГУНУ “Академия финансового управления", Киев, Украина

\title{
НОРМИРОВАНИЕ НАУЧНО-ИССЛЕДОВАТЕЛЬСКОГО ТРУДА: КОНЦЕПТУАЛЬНЫЕ ИСТОКИ
}

\begin{abstract}
Аннотация. Рассмотрены проблемы стандартизации в научной деятельности и особенности оценки качества результатов научных исследований в условиях международной унификации. Цель исследования - бормирование теоретических и методологических подходов к нормированию научно-исследовательской работы. На основе сравнительного анализа литературных источников, действующей нормативной базы и практики определены сушность и отдельные количественные критерии нормирования научной работы. Идентифицированы функции нормирования труда ученого и систематизированы фундаментальные приниипы нормирования творческого труда в научной сфере. Структурирована среда нормирования интеллектуального труда ученого с установлением внутренней и внешней составляюших и уровня воздействия. Выцелены общие и отличительные черты между категориями нормирования научной работы и оченки качества и эфбфективности научной деятельности. Осуществлена классификачия эбфектов от внедрения нормирования научно-исследовательской работь. Охарактеризованы множество взаимосвязей нормирования научной работь и бинансирования научной, научно-технической деятельности. Обоснована роль нормирования научно-исследовательской работь в достижении конкурентных преимуществ в научной сфере. Определены перспективы развития подходов к нормированию труда ученого и возможности совершенствования ее методологии.

К $\Lambda$ ючевые с $\Lambda$ ова: нормирование научно-исследовательского труаа (ННИТ), научно-исследовательские и опытно-конструкторские работы (НИОКР), станАартизация оценивания результативности и эффективности научных исследований, стимулирование научно-исследовательского труАа, интелмектуальный капитац, управление качеством и учет в научном секторе, управцение проектами инновационного развития.
\end{abstract}

Significant attention has to be payed to the fact, that for the economies of modern type in the condition of existence of highly sensitive and widely available systems of information exchange the international technology transfer is 
guaranteeing the rapidly spreading diffusion of the knowledge, eventually the national intellectual capital arises as the strategic resource of retention and additional expansion of notably competitive markets of innovative product. Aggregated cognitive attempts in the national science are prescribing the long-term overall generation of researching initiatives from local scholars, who, as a result, are defining the competitiveness of scientific human capital through the mostly developed technological leaders.

At the same time, the appreciable interest and its further growth for the science research in the field of methodological support of research works is being observed among all sectors of research and development (hereinafter-RED) that are classified by the recognizable approach [1]. Apparently, all representatives of national economy are expecting to obtain and to utilize the whole pool of positive effects form researches enhancement in the sphere of theoretical and methodological points of R\&D.

Considering the statement that was justified within civilization paradigms that scientific knowledge is the founding determinant of nowadays material production [2], the exceptional level of importance and the enough state of incomprehensibility would be appropriate for the analysis of objects and providing subjects of the scientific knowledge as the output of R\&D, including the situation of respectable contribution of the issue from worldwide scientific community.

Recently while substituting the participants of government it is being indicated the migration of the $R \& D$ managing system performers between $R \& D$ sectors, that is a familiar practice for European countries. In fact $R \& D$ managers from business enterprise sector continue their activities in reformation teams of government. Obviously the last ones are trying to approximate the factors of estimation of R\&D efficiency to the categories of profitability and rate of return. Thereby the development of norms firstly for the human resource as the key instrument of standardization is the direct step to implement the above principles.

On the level of government interaction the role of the normalization of scientific and researching labour (hereinafter-NSRL) is connected with all means of optimization of allocation of state budget in the conditions of prioritization of expenditures in the environment of diverse national economic threats [3; 4]. From the other side, NSRL could cause the surplus income of funding of R\&D from external investors as a middle-term influence. The reason of such advantage is the increase of the level of transparency of the information about consumed investment resource that is based on costs control with use of NSRL. Whether the activation of stakeholders would take place on R\&D capital markets, the global implementation of NSRL ideas would definitely have the complex impact.

As to stimulate and to enrich the intellectual capital as the sense-forming resource of R\&D the current forces from scientists` side are accumulated on creating and structuring of theoretical and methodological components of unification and support of scientific and researching labour, which is an outer feature of consolidated knowledge and challenged experience of creative contributors of science.

The dimensions of study clarifying the issue of current overview are well worked out binding together different proclamations from scholars in different areas. Firstly, concept-forming elements were described by [5-8], where the significance of 
intellectual capital and the need of generalization of characteristics of human assets in science were emphasized as to enlarge the outturn from observed phenomenon. Derivative thoughts on necessity of related reforming steps in science and education were illustrated in $[9 ; 10]$ as well as tax protectionism for higher education institutions and R\&D [11]. The details on integration of formula funding because of the requirement of budget legislation amendments based on European Union precedent are contained in achievements of [12]. Mentioned research has been conducting to support government reforms on increasing the quality of education enveloped by the factors of budget expenditures adjustment in the time of crisis. Common items of scientific quality assessment problems were characterized in $[13 ; 14]$ simultaneously with the macroeconomic quantitative provisions of previous research results [4] and applied costs accounting issues of human resource of $R \& D$ were studied in [15].

The certain attention was dedicated to the discussion of scientific labour standardization by Ukrainian scholars [16-18] in specialized studies, where one of the initial models of NSRL was discovered. These authors note that the nature of scientific labour is complicated enough to perform additional research of certain issues on scholars' labour identification.

The active distribution of targeted idea was prefaced by general hypothetic debates on the primary opportunity of evaluation of such a sophisticated thing as scientific labour or labour of scientists. As for now the agreed starting point is that scientific and researching labour has some same factors that are the source description of identifying and counting, where the NSRL could nevertheless succeed.

The preliminary exploration of NSRL topic undoubtedly shows the possibility of extra contribution on uncovered elements about descriptive identifying basics of scientific labour to provide a kind of background for further studies.

Meeting the need of the opportunity of actual research condition the purpose of current study ${ }^{1}$ summarized in the article is to suggest the theoretical and methodological initial components for identifying the process of norming of scientific and researching labour. Outlined purpose could be reached by completing some certain tasks that are:

- to systemize suggested characteristics of scientific and researching labour that influencing the process of NSRL

- to fit general methods of labour norming for the immediate needs of managing and financing human capital in R\&D sector

- to estimate the structure of NSRL environment listing all possible stakeholders.

Quite a long time ago there was formed a thought among society, science and business including theorists and practitioners, on the human prevalence over the most intricate technology and affiliated recognition, exploration and conglomeration of intellect. Such trends were rapidly picked up by commercial sector and caused

1 The study is fulfilling the scientific works plan for the topic "Theoretical and methodological basics for science and practice on norming and stimulating of scientific and researching labour" (0118U000277) of SESE “The Academy of Financial Management”. 
corresponding stratification of practises of purposeful engagement with people from social formations, starting from primitive onlooking factory staff movements [19]. Presently, this area occupies few science domains and practical functions. For the narrow meaning the displayed appearance might be associated with the term of human resource (or human capital) management, that is satisfying the scope of current study.

This is the reason why the science is targeted especially in R\&D on solving fundamental assignments on the future of people in the economy and on strictly directed issues of labour organization for all economic sectors. The analysis of data with use of computer is facilitating the disentanglement of applied aim that consents to extend the accuracy of researching ratings based on numerical methods (deviation, regression and factorial analysis).

The contribution of scientific labour resulting $R \& D$ product as one of the extramural aspect of scientific activity could be hardly characterized because of the limitation of abstract description of mentioned category. Of course the evolution of the research in the particular sphere evokes the necessity of the narration of scientific labour with categories of tangible things, which could be worked up numbers, planning and control. Regarding this study the idea that normalization of scientific and researching labour (NSRL) is a separated category is being promoted.

General thoughts on NSRL in the sphere of $R \& D$ are closely connected with the practice of norming for industrial field of economic goods production. As the labour is being interpreted for the process and the result as the simple resource in physical production complementing equipment or materials, also the labour is being engaged in the process of management for observing of usage and performing of further efficiency estimations. Industrial labour norming is defined as posting some volume and quality characteristics for employees' contribution that is needed for producing of certain request under some organizational and technical conditions $[20 ; 21]$. The reflection of sense of researched term is shown for the norming objects that are working time, production operation, work volume, service perimeter and staff quantity. Coming up as the scientific method [22] labour norming is being involved to diagnose the working process as well as to deliver any implications for enhancing and identifying of scientifically justified norms of labour.

Terminological base of labour norming could not be fully extrapolated for the sphere of $R \& D$, whereas the scientific labour is more unlighted and detailed facing the practice of industry production. It is supposed that scientific and researching labour holds additionally developed creative component and principally eliminates any repeatable ordinary actions [23]. Scientific and researching labour is more likely to be explained as integrated performance of numerous scholar's competencies with the purpose of receiving the brand new experience. This unique experience both contains multifactor complexity so having higher level of generalization oppositely to the industrial labour.

Binding together all signs of scientific activity and the role of scientist as an enterprising creator the following definition of NSRL could be suggested for the nominal understanding along the study. NSRL is standardization planning of creative and risky activities of scientist in the environment of $R \& D$ for building up 
the return on intellectual capital. The disclosure of the sense of NSRL might be also done with use of appropriate scientific methods (observing broad and narrow aspects) and in comparison with another terms in science and technology that would be conducted in extended studies.

The concept and the process of NSRL should be isolated from existent observations on components of scientific researches efficiency assessment and correlating characteristics. Among common features of two mentioned processes the interconnection of incoming and outcoming information outflows is being highlighted for the environment of R\&D. In fact, particular methods of NSRL [24] foresee retrospective matching of current needs with statistic material of alike scientific precedents, when the efficiency assessment involves standardization forecasts and actual information of quantitative and quality indicators on scientific achievement. The key distinguishing point of contrasting processes is the moment of occurrence and documental fixation of norms and assessment, as the labour norm is created before the qualified research which would consume this norm (Figure 1).

Oppositely the assessment result could be get only after scientific research product release, obligatory based on normative figures. In that way NSRL and scientific researches efficiency assessment are interacted as the initial and the secondary accordingly.

NSRL is demonstrating the plural of effects through the system of its functions (Table 1), which are correlating with stages of general production cycle and with the typization of managerial actions in R\&D. The exact function embodies in practice in a form of exceptional results of NSRL in R\&D.

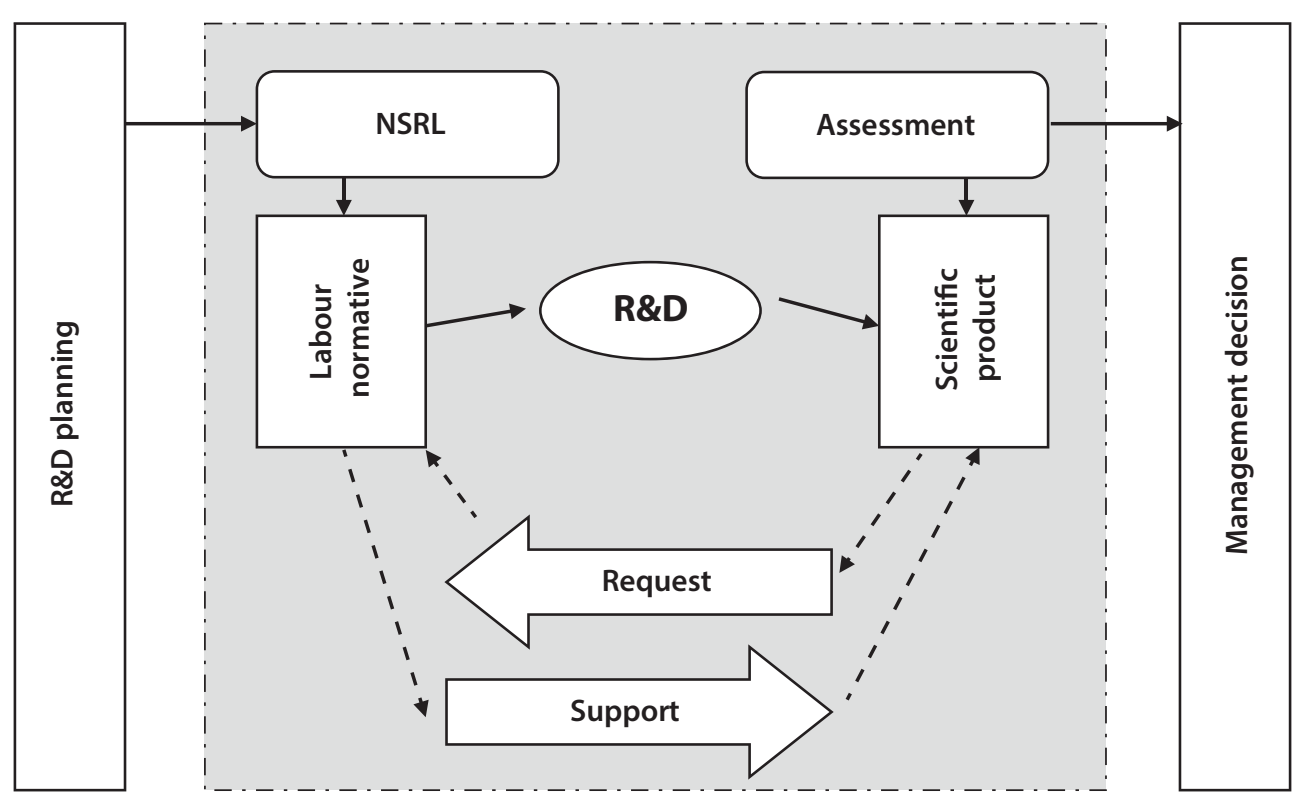

Fig. 1. The interaction between standardization and assessment

Created by author. 
The system of NSRL functions in R\&D

Table 1

\begin{tabular}{|l|c|l|}
\hline \multicolumn{1}{|c|}{$\begin{array}{c}\text { Managerial } \\
\text { resource }\end{array}$} & NSRL function & \multicolumn{1}{c|}{ R\&D reflection } \\
\hline Planning & Standardization & $\begin{array}{l}\text { Gathering criterias for assessment of return of } \\
\text { intellectual capital }\end{array}$ \\
\hline Organization & $\begin{array}{c}\text { Innovation } \\
\text { and rationalization }\end{array}$ & $\begin{array}{l}\text { Search for new approaches in work, } \\
\text { intensification and automation }\end{array}$ \\
\hline Control & $\begin{array}{c}\text { Budgeting } \\
\text { and accounting }\end{array}$ & $\begin{array}{l}\text { Identification and allocation of labour costs, } \\
\text { definition of cost of sale for scientific product }\end{array}$ \\
\hline Motivation & Commercialization & Remuneration of scientists, reinvestment \\
\hline Coordination & Communication & $\begin{array}{l}\text { International exchange of scientific information } \\
\text { and management decision support }\end{array}$ \\
\hline
\end{tabular}

Created by author.

Standardization of scientific labour during the process of NSRL has an inevitable impact on amount of funding of scientific establishments and higher education institutions in the part of R\&D. In case of thorough reasoning of scientific labour exploitation all displays of reform of budget expenditure allocations for science, including the approach of formula funding [25], would be supported by relevant efficiency indicators. This effect would be definitely referred to NSRL results as being the standard number.

Analyzing day-to-day work of a scientist the element of norming might cause the internal rethinking of opportunities to meet established goals. Such surround initiates possible rationating considerations in short-term period, after that in long-term period it might lead to unexpected breakthrough almost comparing to process innovation by J. Schumpeter [26].

On the stage of control in R\&D the policy and the results of NSRL tend to provide the formation of functional fundament for objective and comprehensive application of management accounting practices after processing of suitable scientific source information. For example, the collection of data over consistent budget periods is likely to decrease the statistic mistake while calculating the cost of scientific product directly for the allocation of indirect costs. The figures of normative scientific and researching labour also could be used in analysis of nonfinancial ratios [27] of activities inspections, significantly for the calculation of competitiveness impact.

Motivation part of NSRL is being uncovered in approximation of remuneration expectations of scientists to the actual compensation of scientific and researching labour dependent on analysis of efficiency estimations. Whether NSRL would formalize the vector, represented from one side by primary guides on human resource costs for the research, and reflected by quality characteristics of finished scientific product from another side, there would be emerging strong reasons to stimulate the involved personnel by all possible instruments of material and 


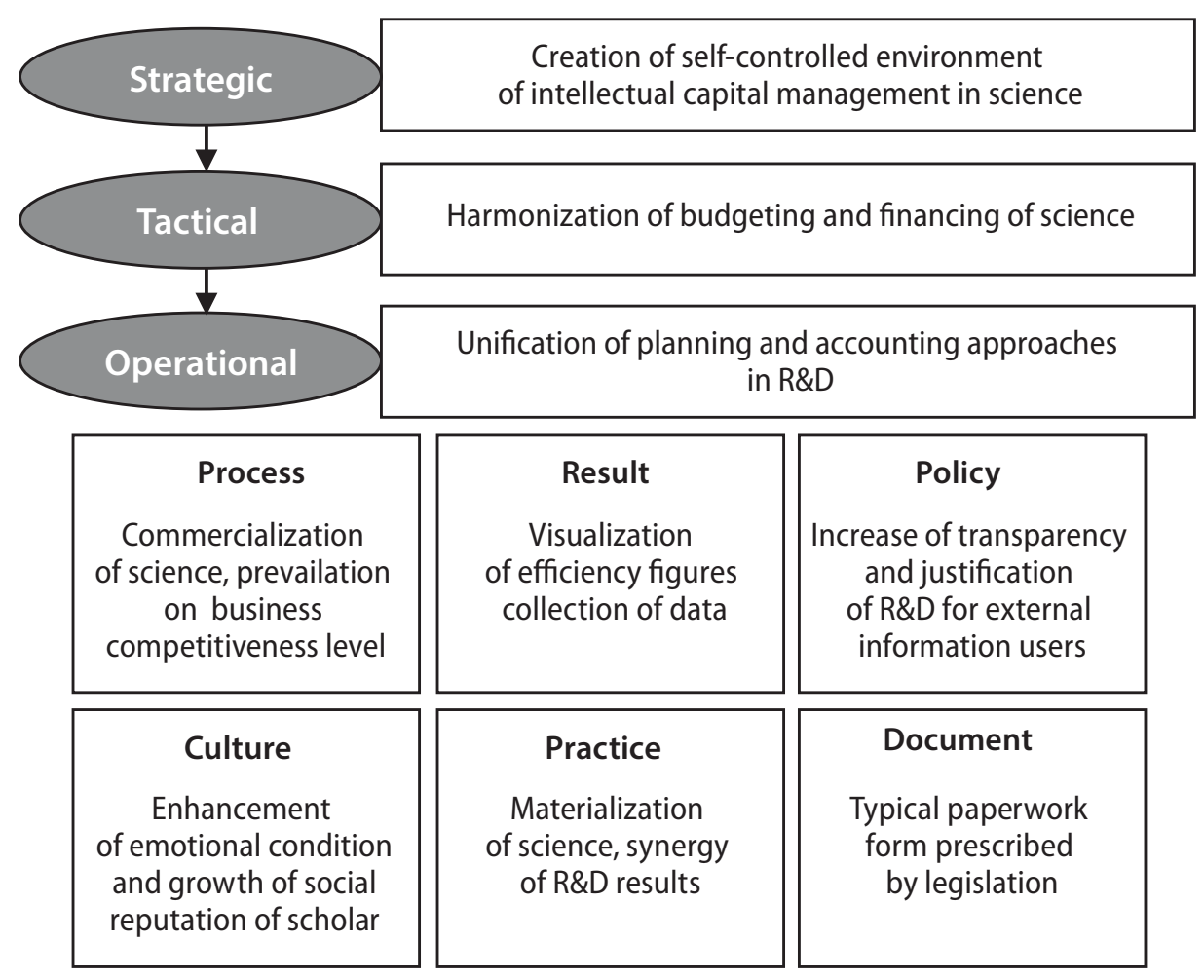

Fig. 2. Prioritization of attempts in the sphere of implementation of NSRL

Created by author.

appreciation rewards. For applied aspect NSRL might boost the sensibility of scientific labour assessment scale and could assist the development of scientific streams of separating of fixed and varied parts of scholar financial compensation.

Being influenced by acquisition of national science from European community standards the systematic performance of communication function would proclaim the state of Ukrainian science labour intensity and would cause the prestige reflection both for R\&D sector and economy as the whole. On the level of mutual integration of worldwide scientific society with national representatives the accounting of scientific statistic information (i.e. labour cost) about absolute and relevant indicators of scientists ` performance, resulting efficiency outlook, would assure the income of external knowledge for the gain of domestic R\&D [28]. This effect would surely specify the level of potential of Ukrainian scholars, and from another side donating to the level of justification of management decisions within the execution in $R \& D$ sector.

Due to accomplish all functions of NSRL appropriate persistence could be distributed on some priorities with certain countable results (Figure 2).

The non-intermediary fulfilment of norming could be conducted in the environment of participants NSRL. The representatives from each sector of R\&D are acting in NSRL as consumers or providers and are taking strict roles (Figure 3). The unique location in the structure of cooperation is being held by R\&D manage- 


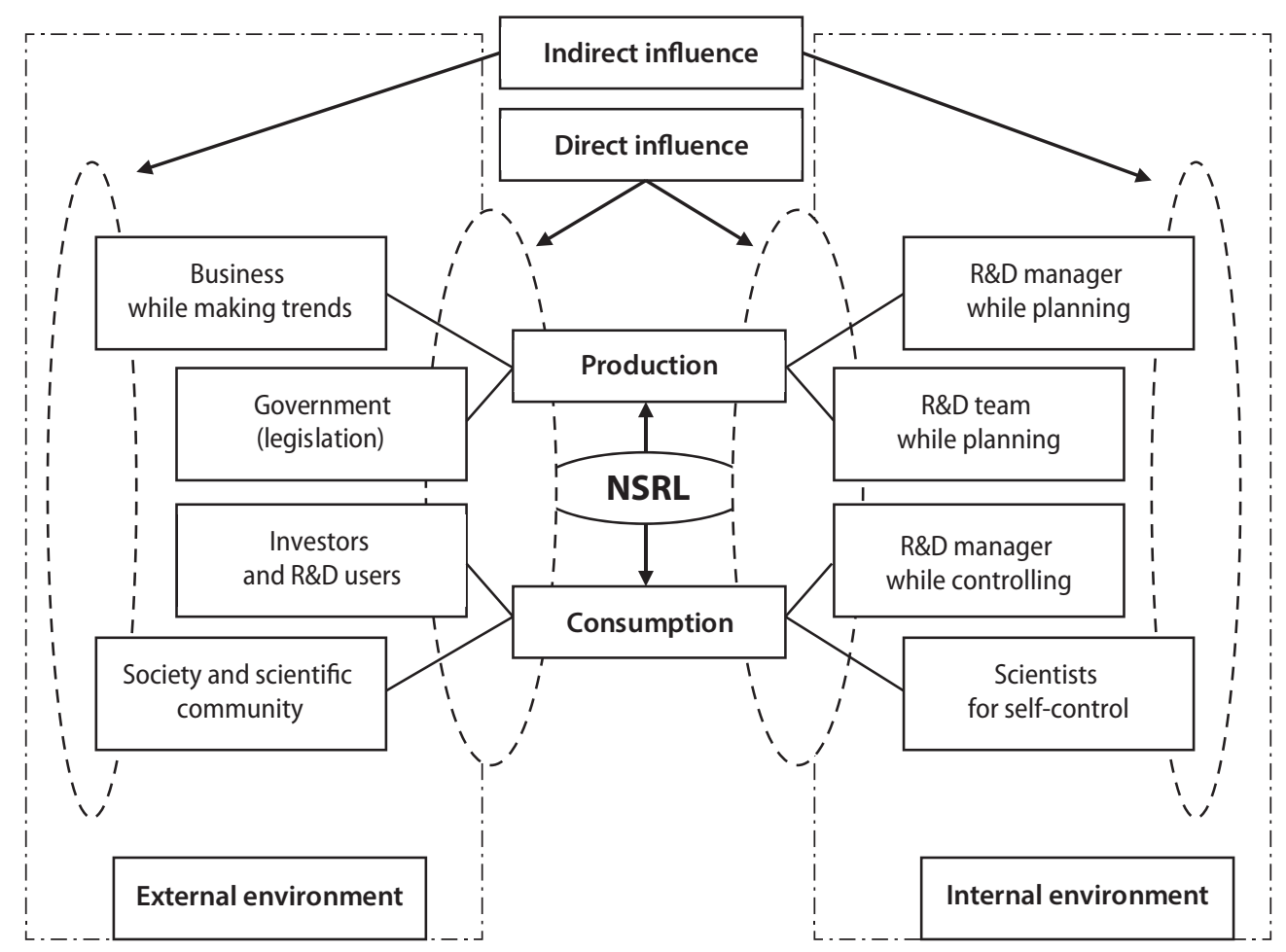

Fig. 3. Roles of participants of NSRL

Created by author.

ment and business. Finding out the layer of interaction structure of NSRL R\&D manager operates either on the stage of planning or control, relatively using analytical instruments to set the norm and critical thinking while making management decisions after control.

From the other side, business sector indirectly brings some trends of scientific research evolution for exact industry, and summarizing NSRL results business experts outline the necessity of additional funding of chosen sphere. Consequently, positive marks of the efficiency of scientific labour that was invested in before would show the multiplicative effect on extra resource provision (technology, finance and infrastructure).

With high level of importance the process of norming have to be reviewed from the position of quality management. It keeps an attention of scientists during the completing theoretical and methodological supplements for scientific labour support. Based on analysis of quality management techniques [29] main extrapolations could take place.

It has to be emphasized that the synergic advantages from suggested NSRL cycle implementation could be attained only after unavoidable and systematic iteration of all stages with mandatory experience element, which is prescribed as an indirect product of science and practice combination (Figure 4). 


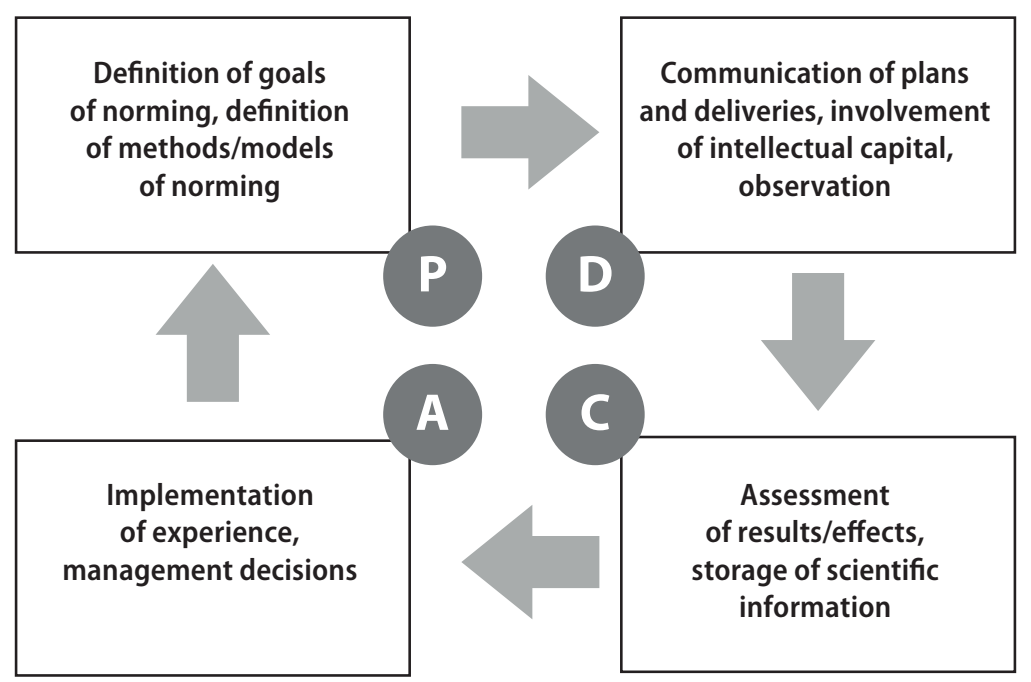

Fig. 4. PDCA cycle for NSRL

Created by author.

Additionally, fundamental principles were extracted as triadic manifest of quality management. The idea would stay the same while aggregating principles of NSRL. The NSRL principles triad consists of:

- efficient goal-setting process of NSRL, considering all expectations from counterparties;

- intensification of control, automation, impersonation;

- culture of initiativity and continuous improvement.

Iteration reflection based on triadic principles as being the part of NSRL concept means that there would be held regular and compulsory collection of quality achievements for the needs of next cycle passage. Moreover, unsolved part of circumstances has to be revised with use of alternative methods of scientific cognition. Generally, the continuous improvement which is a quite efficient tool of management [29] could be implemented into the theoretical and methodological complex of NSRL in R\&D, presenting it as ideological thesis of cultivation of quality of scientific research.

Wide-scope roll-out of the NRSL policy could be done entirely after the complex proof of quantity of significant effects that the study object might accumulate in the name of sustainable development. The interim survey of NSRL environment provides the need in localization of such weights by terminal and covering criterias. The author's order of effects is presented in the Table 2.

Not to overwhelm the core sense it has to be stated that the range of impact of NSRL approach could come to the achievement of knowledge-based economy [30]. For mentioned scenario the economy would consume the product of tangible scientific labour for the preference of society.

As it is seen from the matrix the identification of synthetic effects of NSRL might be received after the conduction of emerging studies outside the scientific and technical activities sphere. Particularly the cross-discipline direction might 
NSRL global effects matrix

\begin{tabular}{|c|c|c|c|c|}
\hline \multirow{4}{*}{ ֻ } & $\sum_{\substack{\infty \\
\infty}}^{\stackrel{\pi}{\infty}}$ & Synthetic effects & Synthetic effects & $\begin{array}{l}\text { Knowledge-based } \\
\text { economy expansion }\end{array}$ \\
\hline & 莺 & Synthetic effects & Synthetic effects & $\begin{array}{l}\text { Materialization } \\
\text { of scientific potential, } \\
\text { erasing the borders } \\
\text { between business } \\
\text { and government R\&D }\end{array}$ \\
\hline & 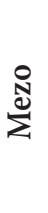 & $\begin{array}{l}\text { Preparation of planning and } \\
\text { accounting policies for R\&D, } \\
\text { expansion of standardization } \\
\text { activity on the cross-sectoral } \\
\text { R\&D units }\end{array}$ & $\begin{array}{l}\text { Reformation of science } \\
\text { funding, appreciation of } \\
\text { science contribution }\end{array}$ & $\begin{array}{c}\text { Self-regulating } \\
\text { environment } \\
\text { of R\&D performers }\end{array}$ \\
\hline & 을 & $\begin{array}{l}\text { Utilization of concept } \\
\text { and methods of NSRL } \\
\text { by R\&D performers, } \\
\text { in priority for SME }\end{array}$ & Synthetic effects & Synthetic effects \\
\hline & & Short-term & Middle-term & Long-term \\
\hline & & & Period & \\
\hline
\end{tabular}

Created by author.

harvest great ideas while discovering behaviour aspects of the economy [31] and psychological component of the motivation of scientist, competing with the general look on intellectual activity of humanity at all.

For utilization of scientific abstraction in the study of the role of human resources in science there could be built the cycle "economy-state budget-scienceeconomy". Accordingly the described order is familiar to industrial production process of the enterprise. At that case some investment resource (GDP share) by using some organizational forms (state finances) is shifted to contingent incomegenerating unit (scientific sector), which provides added value (scientific product) for the partial reinvestment (economy). Especially simultaneous inclusion of all parts of the chain would ensure the symbiotic evolution. Indeed, it might be added that the movement of resource through described chain explains the recovering function of the science.

As to highlight the apparent level of volatility of government during the reformation, the account and trust to the scientific return is high including overrunning quantitative goals. For that reason discussing approaches in the sphere of $R \& D$ are imposing from the executives the notable input of discipline and competent responsibility for implementation, what is surely equal to the commercial activities. 
The place of NSRL in science funding might be characterized as the pulling-out tool that polemize with Asian management milestone [29]. It means that the result of standardization shall initially claim the process of funding, because the situation of division of highly approved isolated budget based on weak normative assumptions would not have any influence on efficiency management.

Concluding the conducted study it could be insisted that NSRL is the initial step of labour organization in the scientific sector, what causes the further adaptation of general intellectual capital management concept for the science. The suggested conceptual preview would influence the additional development of NSRL methodology firstly to practical application of norming policies through all R\&D units between all classified sectors. This study could be transferred on different economy industries`recommendations paying attention to sectoral peculiarities of scientific and researching labour.

The probable step in state regulation system might be done in the form of integration of formula funding legislation with standardization approach. The legislation in the sphere of NSRL need to be incorporated and analyzed critically based on the assumptions of current research.

Ambitious opportunities have also to be listed, where the expected synthetic result is linked to the adaptation of management accounting theory to the requested issues of cost ordering within the scientific sector. As for now less covered part of knowledge is dedicated to improvements of program-targeted method with use of commercial project management methodology [32; 33]. Because of similar metrics of the efficiency issue the preparation of models of $R \& D$ projects management is inducing the high interest and importance.

\section{References}

1. OECD. (2015). Frascati Manual 2015: Guidelines for Collecting and Reporting Data on Research and Experimental Development, The Measurement of Scientific, Technological and Innovation Activities. DOI: 10.1787/9789264239012-en.

2. Toffler, E. (2000). The Third wave. Kyiv: Vsesvit [in Ukrainian].

3. Iefymenko, T. I. (2017). Some aspects of the public discussion of a draft Medium Term Plan of Priority Actions until 2020. Finance of Ukraine. 1, 7-9. DOI: 10.33763/ finukr2017.01.007 [in Ukrainian].

4. Bohdan, I. V., \& Konovalenko, D. V. (2018). International comparisons of researcher's labor productivity and macroeconomic effects of research and development. Finance of Ukraine, 12, 52-71. DOI: 10.33763/finukr2018.12.052 [in Ukrainian].

5. UNESCO. (1978, November 28) Records of the General Conference, 20th session. Retrieved from https://unesdoc.unesco.org/ark:/48223/pf0000114032.page=188.

6. Emerson, H. (1912). The twelve principles of efficiency. Retrieved from https://archive. org/details/twelveprinciples00emerrich/page/n19/mode/2up.

7. Machlup, F. (1962). The production and distribution of knowledge in the United States. Princeton University Press.

8. Pavliuk, K. V. (2019). Methodical approaches to the evaluation of the quality of scientific research. RFI Scientific Papers, 2, 5-17. DOI: 10.33763/npndfi2019.02.005 [in Ukrainian].

9. Rainova, L. B. (2018). Formula funding of higher education in EU countries. RFI Scientific Papers, 2, 133-145. DOI: 10.33763/npndfi2018.02.133 [in Ukrainian].

10. Pavliuk, K.V. (2019). Problems of evaluation of scientific activity. RFI Scientific Papers, 4, 5-19. DOI: 10.33763/npndfi2019.04.005 [in Ukrainian]. 
11. Tochylina, I. V. (2018). International expierence of tax incentives for higher education development. RFI Scientific Papers, 3, 48-64. Retrieved from http://npndfi.org. ua/?page_id=723\&aid=943 [in Ukrainian].

12. Sokolovska, A. M. (2018). Discussion aspects of formula distribution of state expenditure on higher education in Ukraine. Finance of Ukraine, 5, 8-21. DOI: 10.33763/ finukr2018.05.008 [in Ukrainian].

13. Kaminska, O. S. (2018). Rationing of scientific research work and its role in efficiency and quality improving of scientific research work. RFI Scientific Papers, 4, 94-105. DOI: 10.33763/npndfi2018.04.094 [in Ukrainian].

14. Pavliuk, K. V., Kaminska, O. S. (2019). Foreign experience of assessing the quality of scientific activity. RFI Scientific Papers, 3, 25-40. DOI: 10.33763/npndfi2019.03.025 [in Ukrainian].

15. Korytnyk, L. P. (2019). Conceptual principles of forming budgets in management accounting of higher education institutions. Finance of Ukraine, 8, 75-88. DOI: 10.33763/finukr2019.08.075 [in Ukrainian].

16. Gasanov, S. S., Kotlyarevskyy, Ya. V., Melnikov, A. V., Kniaziev, S. I., Shtangret A. M., \& Semenyuk, E. P. Gasanov, S.S. (2019). Methodological Approaches to Labor Norming in Scholarly Research and Development. Science and Innovations, 15, 5-27. DOI: 10.15407/scin15.01.005 [in Ukrainian].

17. Gasanov, S. S. (2019). Research and development (R\&D) in the national economy structure: trends of employment, expenditures and funding. RFI Scientific Papers, 1, 5-17. DOI: 10.33763/npndfi2019.01.005.

18. Gasanov, S.S. (2018). Research and development (R\&D) in the national economy structure: connections with government functions. RFI Scientific Papers, 3, 5-17. DOI: 10.33763/npndfi2018.04.005 [in Ukrainian].

19. Taylor, F. W. (1911). The Principles of Scientific Management. Retrieved from https:// sites.ualberta.ca/ yreshef/orga432/docs/TaylorScientificManagement.pdf.

20. Babenko, A. H., \& Bondarevska, K. V. (2013). Labour norming: educational handbook. Dnipropetrovsk: Dnipropetrovsk State Financial Academy [in Ukrainian].

21. Chase, R. B. (2008). Operations Management for Competitive Advantage. Moscow: Viliams [in Russian].

22. Chervaniov, D. M., \& Zhylinska, O. I. (2001). Cross-discipline vocabulary of management. Kyiv: Nichlava [in Ukrainian].

23. Lopatynska, L. A. (2019). Modern level of evolution of methodology and methods of scientific labour norms creation. RFI Scientific Papers, 3, 41-50. DOI: 10.33763/ npndfi2019.03.041 [in Ukrainian].

24. Iefymenko, T. I., Gasanov, S. S., Bogdan, I. V. (2018). State budget expenditures on higher education: structural changes and formula allocation problem. Bulletin of Kyiv National University of Technology and Design. Series: Economic Sciences. Retrieved from https://er.knutd.edu.ua/handle/123456789/10114 [in Ukrainian].

25. Pavliuk, K.V. (2019). Interrelation of research findings and financing of science: foreign experience. Finance of Ukraine, 3, 73-91. DOI: 10.33763/finukr2019.03.073

26. Sandefur, T. (n. d.). Innovation: the description of process innovation by J. Schumpeter. Retrieved from https://www.econlib.org/library/Enc/Innovation.html

27. Kaplan, R. S., \& Norton D. P. (2013). Balanced scorecard system. Moscow: Olimp-Biznes [in Russian].

28. Yegorov, I. Yu. (2016). System of Integrated Indicators for the Assessment of ScientificTechnical and Innovation Activities in the Context of European Integration. Science and Innovations, 4, 19-21. DOI: 10.15407/scin12.04.019 [in Ukrainian].

29. Imai, M. (2014). Gemba Kaizen: A commonsense, low-cost approach to management. Moscow: ALPINA PABLISHER [in Russian]. 
30. Knowledge-based economy (2009, September 9). OECD Glossary of Statistical Terms. Retrieved from https://stats.oecd.org/glossary/detail.asp?ID=6864.

31. Kenton, W. (2019, May 6). Behavioural economy. Investopedia. Retrieved from https:// www.investopedia.com/terms/b/behavioraleconomics.asp.

32. Demydenko, R. (2018). Initiation of project approach in the sphere of innovation development of national economy. Actual problems of management of social and economic systems, 49-50 [in Ukrainian].

33. Kaminska, O. S. (2019). State stimulation of the quality level of research work. RFI Scientific Papers, 4, 20-34. DOI: 10.33763/npndfi2019.04.020 [in Ukrainian].

\section{Список використаних Ажерем}

1. Frascati Manual: Guidelines for Collecting and Reporting Data on Research and Experimental Development, The Measurement of Scientific, Technological and Innovation Activities / OECD. 2015. 400 p. URL: https://doi.org/10.1787/9789264239012-en.

2. Тобблер Е. Третя хвиля. Київ : Всесвіт, 2000. 480 с.

3. Єळименко T. I. Деякі аспекти громадського обговорення проекту Середньострокового плану пріоритетних дій на період до 2020 року. Фінанси України. 2017. № 1. C. 7-9. URL: https://doi.org/10.33763/finukr2017.01.007.

4. Богдан I. В., Коноваленко Д. В. Міжнародні порівняння продуктивності праці дослідників та макроекономічного ефекту досліджень і розробок. Фінанси Украйни. 2018. № 12. C. 52-71. URL: https://doi.org/10.33763/finukr2018.12.052.

5. Records of the General Conference, 20th session. Paris : UNESCO, 1978. URL: https:// unesdoc.unesco.org/ark:/48223/pf0000114032.page $=188$.

6. Emerson $H$. The twelve principles of efficiency. 2012. URL: https://archive.org/details/ twelveprinciples00emerrich/page/n19/mode/2up.

7. Machlup F. The production and distribution of knowledge in the United States. Princeton University Press, 1962. $416 \mathrm{p}$.

8. Павлюк К. В. Методичні підходи до оцінки якості наукових досліджень. Наукові праці НДФІ. 2019. № 2 С. 5-17. URL: https://doi.org/10.33763/npndfi2019.02.005.

9. Райнова Л. Б. Формульне фінансування вищої освіти в країнах ЄС. Наукові праці НДФІ. 2018. № 2. С. 133-145. URL: https://doi.org/10.33763/npndfi2018.02.133.

10. Павлюк К. В. Проблеми оцінювання наукової діяльності. Наукові праці НДФІ. 2019. № 4. C. 5-19. URL: https://doi.org/10.33763/npndfi2019.04.005.

11. Точиліна I. В. Міжнародний досвід податкового стимулювання розвитку сфери вищої освіти. Наукові праці НДФІ. 2018. № 3. С. 48-64. URL: http://npndfi.org. ua/?page_id $=723 \&$ aid $=943$.

12. Соколовська А. М. Дискусійні аспекти формульного розподілу бюджетних видатків на вищу освіту в Україні. Фінанси України. 2018. № 5. С. 8-21. URL: https://doi. org/10.33763/finukr2018.05.008.

13. Камінська О. С. Роль нормування науково-дослідної праці у підвищенні її ефективності та якості. Наукові праціі НДФІ. 2018. № 4. С. 94-105. URL: https://doi.org/10.33763/ npndfi2018.04.094.

14. Павлюк К. В., Камінська О. С. Зарубіжний досвід оцінки якості наукової діяльності. Наукові праці НДФІ. 2019. № 3. С. 25-40. URL: https://doi.org/10.33763/npndfi2019.03.025.

15. Коритник Л. П. Концептуальні засади формування бюджетів в управлінському обліку закладів вищої освіти. Фінанси України. 2019. № 8. C. 75-88. URL: https://doi. org/10.33763/finukr2019.08.075.

16. Методологічні підходи до нормування праці у сфері наукових досліджень та розробок / С. С. Гасанов, Я. В. Котляревський, О. В. Мельников, та ін. Наука та інновації. 2019. Т. 15. № 1. С. 5-27. URL: http://scinn.org.ua/en/archive/15(1)/15(1)01. 
17. Gasanov S. S. Research and development (R\&D) in the national economy structure: trends of employment, expenditures and funding. Наукові праці НДФІ. 2019. № 1. С. 5-17. URL: https://doi.org/10.33763/npndfi2019.01.005.

18. Гасанов C. С. Дослідження і розробки (R\&D) у структурі національної економіки: методологія міжнародних порівнянь. Наукові праці НДФІ. 2018. № 3. C. 5-17. URL: https://doi.org/10.33763/npndfi2018.04.005.

19. Taylor F. W. The Principles of Scientific Management. 1911. URL: https://sites.ualberta. $\mathrm{ca}$ /yreshef/orga432/docs/TaylorScientificManagement.pdf.

20. Бабенко А. Г., Бондаревська К. В. Нормування праці : навчально-наочний посібник для студентів денної та заочної форм навчання. Вид. 2-ге, доповн. Дніпропетровськ : Дніпропетровська державна фінансова академія, 2013. 158 с.

21. Чейз Р. Б. Производственный и операционный менеджмент. 10-е изд. : пер. с.англ. Москва : ООО “И.Д. Вильямс", 2008. 1184 с.

22. Міждисциплінарний словник з менеджменту / [за ред. Д. М. Черваньова, О. I. Жилінської]. Київ : Нічлава, 2001. 624 с.

23. Лопатинська Л. А. Сучасний рівень розвитку методології і методів розроблення нормативів науково-дослідної праці. Наукові праці НДФІ. 2019. № 3. С. 41-50. URL: https://doi.org/10.33763/npndfi2019.03.041

24. Єळименко T. I., Гасанов С. С., Богдан I. В. Видатки державного бюджету на вищу освіту: структурні зміни та проблема формульного розподілу. Вісник Київського національного університету технологій та дизайну. Сер.: Економічні науки. 2018. Спецвипуск: Ефективність організаційно-економічного механізму інноваційного розвитку вищої освіти України : матеріали VIII Міжнародної науково-практичної конференції (5 жовтня 2018 р., м. Київ). С. 27-51. URL: https://er.knutd.edu.ua/ handle/123456789/10114.

25. Павлюк К. В. Взаємозв'язок результатів науково-дослідної праці та фінансування науки: зарубіжний досвід. Фінанси України. 2019. № 3. С. 73-91. URL: https://doi. org/10.33763/finukr2019.03.073.

26. Sandefur T. Innovation: the description of process innovation by J. Schumpeter. URL: https:// www.econlib.org/library/Enc/Innovation.html.

27. Каплан P., Нортон Д. Сбалансированная система показателей. Москва : ЗАО “ОлимпБизнес", 2013. 314 с.

28. Єгоров I. Ю. Система комплексних індикаторів оцінки науково-технічної та інноваційної діяльності в контексті процесів євроінтеграції. Наука та інноваціі. 2016. T. 12, № 4. C. 19-21. URL: https://doi.org/doi.org/10.15407/scin12.04.019.

29. Имаи М. Гемба кайдзен: Путь к снижению затрат и повышению качества. Москва : АЛЬПИНА ПАБЛИШЕР, 2014. 416 с.

30. Knowledge-based economy. OECD Glossary of Statistical Terms. 2009. September 9. URL: https://stats.oecd.org/glossary/detail.asp?ID=6864.

31. Kenton W. Behavioral economy. Investopedia. 2019. May 6. URL: https://www.investopedia. com/terms/b/behavioraleconomics.asp.

32. Демиденко Р. К. Запровадження проектного підходу в сфері інноваційного розвитку національного господарства. Актуальні проблеми управління соціальноекономічними системами: матеріали міжнар. наук.-практ. інтернет-конф., Луцьк, 7 груд. 2018 р. Ч.1. С. 49-50.

33. Камінська О. С. Аержавне стимулювання якісного рівня результатів науковоАосліАної праці. Наукові праці НАФI. 2019. № 4. С. 20-34. URL: https://doi. org/10.33763/npndfi2019.04.020. 